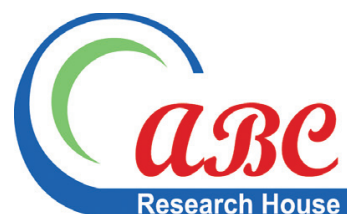

Access this article online

Website:

www.ajtp.us

Volume 1

Number 1/2014

Issue 1

DOI:

Licenced: (CC) $\$(\mathrm{BY}$

E-mail for correspondence:

love.chile@aut.ac.nz

Received: September 11, 2013

Accepted: November 17, 2013

Published: June 30, 2014

\section{The Paradox of Agricultural Trade Liberalization in Bangladesh and Tanzania}

\author{
Love M. Chile ${ }^{1}$, Dayal Talukder ${ }^{2}$ \\ ${ }^{1}$ Associate Professor, Institute of Public Policy, School of Social Sciences and Public Policy, Auckland \\ University of Technology, Auckland, New Zealand \\ 2Lecturer, ICL Business School, Auckland, New Zealand
}

\begin{abstract}
This paper examines some of the contradictions and theoretical ambiguities of agricultural trade liberalizationon the welfare of smallholder farmers. Using production, consumption and price data for pre-and post-liberalization periods for two main agricultural crops from Bangladesh (rice) and Tanzania (maize) we critically analyse the correlation between domestic and international prices of rice in Bangladesh and maize in Tanzania to estimate impact of agricultural trade liberalization on price stability/volatility and food security to measure economic benefits of trade liberalization on smallholder farmers. Using coefficient of variation of the level of prices (CV) and corrected coefficient of variation (CCV) as measured by Huchet-Bourdon (2011) we found that the values of both $\mathrm{CV}$ and $\mathrm{CCV}$ for consumer price in the post-liberalisation were quite large suggesting greater volatility of consumer price of rice in Bangladesh and maize in Tanzania in the post-liberalization period. We conclude that price volatility diminishes the potential benefits of agricultural trade liberalization forsmallholder farmers who are net-deficit producers, net-deficit sellers and recommend supplementary policy interventions to achieve enhanced welfare from trade liberalization.
\end{abstract}

Keywords: Agricultural trade liberalization, Rice production consumption and trade in Bangladesh, Maize production consumption and trade in Tanzania, Price volatility

\section{Introduction}

Agriculture plays a central role in the economy and lives of all countries, but most significantly the least developed countries in terms of employment, industrial raw materials, food security, and international, regional and sub-national trade and exchange. It has been argued that agricultural trade restrictions limit the potential benefits that countries that are highly dependent on agriculture would derive from unrestricted access to international and regional markets. Theoretically the benefits of agricultural trade liberalization include growth in nations' gross domestic product [GDP], increase in farmers' incomes and overall reduction in rural poverty, particularly poverty of those dependent on agricultural production, national and family food security. The gains from agricultural trade liberalisation are generated through multiplier factors such as productivity improvements leading to higher output per farmer/area, technological innovation in agriculture (Ahmed and Sattar, 2004: 19; Islam and Habib, 2007: 4; Klytchnikova and Diop, 2006: 3). Furthermore, liberalisation of the input markets for fertilisers, pesticides, irrigation equipment and adoption of high yielding variety seeds results in significant increase in productivity and growth in the agricultural sector further multiplying the benefits of agricultural trade liberalization. It is therefore argued that agricultural trade liberalisation influences the long-run growth of national economies (Chang, et al., 2009: 1; McCulloch et al., 2003: 21; Meschi and Vivarelli, 2009: 287; Montalbano, 2011: 1).

However, these theoretical benefits are based on a number of assumptions such as transfer or reallocation of resources such as labour and capital between sectors (Montalbano, 2011: 1; Stone and Shepherd, 2011: 5), price stability (Foster, 2008: 544; Krueger, 2010: 5), and rural infrastructure development. 
The economies of the two case study countries examined in this paper, Bangladesh and Tanzania are predominantly agricultural. In both countries agriculture constitutes the major employer of labour (Tanzania 80 percent, Bangladesh 45 percent), it is also the primary contributor to foreign exchange earnings and gross domestic product for Tanzania at 60 percent and 50 percent respectively (Tanzania Agriculture Trade Information Centre, 2013). While in Bangladesh agriculture contributed a significant 18.7 percent to GDP in 2010 (Bangladesh Ministry of Agriculture, 2013), and more than 80 percent of export products in 2007-2008 were from cotton and jute-based manufactured garments (Bangladesh Ministry of Finance, 2009).

In this paper we argue that for least developed countries such as Bangladesh and Tanzania, agricultural trade liberalization presents a paradox, where by the welfare gains postulated in theoretical analyses may not often be obtained to create long-term sustainable welfare outcomes presented in policy briefs. Using output data for two main agricultural crops from Bangladesh (rice) and Tanzania (maize) we critically examine the contradictory outcomes of agricultural trade liberalization on the welfare ofsmallholder farmers. We select maize and rice for analysis because maize accounts for about 32 percent of total food production in Tanzania, and about 75 percent of all cereal consumption, as wellas about 85 percent of Tanzania's population depend on it as an income generating commodity. In the case of Bangladesh rice is a stable food for more than 80 percent of the population. We conclude that as most rural agricultural producers are subsistence smallholder farmers, they lose both as net sellers in high seasons and net buyers in low season and income gains from trade liberalization accrue more to medium-to-large producers and also to intermediary syndicates thus increasing the gap between rich and poor in rural areas. For trade liberalization to achieve the theoretical outcome of enhanced welfare, smallholder farmers should be able to sell their produce at the best possible price in a stable predictable market.

\section{Agricultural Trade Liberalization}

Agricultural trade liberalization refers to the process of removing tariffs, regulations and other instruments and barriers perceived to obstruct free flow of agricultural products and services between trading areas (Eicher et al., 2009: 144). The benefits of agricultural trade liberalization have been highlighted to include specifically raising the welfare of smallholder farmersthrough income growth and enhanced living standards, and more equitable income distribution. Theoretically trade liberalization may deliver benefits through market access, expanding the demand for goods and services of domestic firms, enabling firms to reach larger markets, gains from economies of scale, and increased economic growth rates due to short run gains from resource reallocation (Stone and Shepherd, 2011: 5; Zhang, 2008: 175). Although difficult to measure (Rodriguez, 2007: 11) the dynamic gains shift production possibility frontier outward thus widening the total domestic market.

However, liberalization may also translate into lower commodity/produce prices for labour intensive smallholder farmers resulting in lower welfare gains for smallholder farmer households. It could reduce the wages of unskilled labour thereby widening the income gap between the rich and poor(Acharya, 2011: 60; Falvey, et al., 2010: 230; Keleman, 2010: 13).

The theoretical ambiguity of the effects of trade liberalisation is reflected in the contest between studies that point to strong positive growth effects and those thatdocument negative impacts on household welfare. Although many developing countries adopted agricultural trade liberalisation and market reform from the mid-1980s in response to the re-emergence of development paradigm based on neo-classical orthodoxy, (Gingrich and Garber, 2010: 2; Rahman, 2008: 11),with the primary focus onintroducing market forces into national agricultural trade by reducing government control of agricultural input and output markets, lowering tariff and non-tariff barriers, the expected outcomes to improve agricultural productivity, boost rural incomes and reduce poverty are at best mixed. Some of the challenges faced by least developed countries such as Bangladesh and Tanzania include the fluctuations and disparities in international market prices for key agricultural trade products and diminishing export opportunities, competition between domestic producers and imports for agricultural trade prices that may be significantly lower than cost of production, and the lack of investment in rural infrastructure to enhance the multiplier effects in agricultural to increase total factor productivity to achieve pro-poor growth.

\section{Agricultural Trade Liberalization Poverty Reduction and Welfare Enhancement}

The poverty reduction and welfare enhancement effects of the agricultural trade liberalization-driven growth paradigm is predicated on arguments that increased agricultural productivitywill directly and indirectly impact on the price of food for net buyers, generateemployment in both farm and non-farm sectors, and enhance income and earnings potential through higher wages (Mosley and Chiripanhura, 2009: 751; Popli, 2010: 803). Furthermore, growth linkage with the non-farm sectormay be realised through agricultural-demandled-industrialisation (Adeoti and Sinh, 2009: 6; Islam and Habib, 2007: 4; Williams and Smith, 2008: 8).

However, the welfare gains and losses must also be examined with regards to distributional consequences, how income gains are distributed and what happens to average living standards of the rural households. Poverty reduction is not simply a function of productivity growth but also depends on public policies relating to inequalities and the extent to which economic growth is pro-poor. Bezemer and Headey (2008) suggest that to ensure that productivity growth, improved farm income, higher employment, and food prices lead to pro-poor outcomes agricultural productivity per unit of labour must increase at a faster rate than that of labour in order to raise employment and rural wages, and total factor productivity (TFP) in agriculture must increase faster than food prices decrease for farm profitability to rise and for poor consumers to benefit from lower food prices. Therefore, the net effect of agricultural trade liberalisation on poverty reduction and 
the welfare of rural households depend on the direction of price changes andhow they affect domestic factor prices. If the price changes are pro-poor then they will tend to reinforce positivegrowth effects of agricultural trade reform on the poor (Susila and Bourgeois, 2008: 75).

\section{Agricultural Trade Liberalization in Tanzania and Bangladesh}

Tanzania's trade policy may be divided into three phases, namely 1960-to-mid-1980s when government policy was based on inward-looking state socialism which sought selfsufficiency in food production. From the mid-1980s to the mid-1990s state reforms based on International Monetary Fund [IMF] and World Bank prescriptions introduced the process of trade liberalization in 1986 as part of the overall national economic recovery programme $[\mathrm{ERP}]$ and the economic and social action plan [ESAP]. This phase was characterised by structural adjustment programmes [SAP] which removed export taxes on export crops, liberated domestic food market, and opened up import markets for agricultural inputs, machinery and technology. Phase three began about 1996 when the new government entered into a new agreement with the IMF on a three-year ESAP, and the relationship with the other donors to move forward with the economic and social reform process. Agricultural trade liberalization progressed through the 1990s and was fully in place by 2000. Government trade policy objective was to provide "ways and means of ensuring a viable and steady path towards competitive export-led growth which will fulfil the goal of poverty eradication" (Economic and Social Research Foundation, 2010:26). Although there is general agreement amongst economic analysts that "so far Tanzania has not been able to derive significant benefits from trade liberalization as well as globalization as a whole, due to inadequate supply and delivery capacity with low technology levels, insufficient physical and human capital and underdeveloped infrastructure" (Economic and Social Research Foundation, 2010:26).

Similar to Tanzania, Bangladesh trade liberalization policy may be divided into three phases, namely 1972-1980 characterised by severe agricultural trade controls on both exports and imports, including non-tariff barriers [NTBs] and heavy duties, fixed exchange rate system, massive nationalisation, price control, and control of agricultural inputs and marketing. Phase two 1981-1990 was the phase when agricultural trade liberalization started with some relaxation of NTBs and tariff barriers, and the beginning of denationalisation, deregulation and removal of price controls and significant liberalisation of agricultural sector input and output markets. During phase three 1991-2002 liberalisation of agricultural trade and investment was fully implemented with large scale reductions of NTBs and average tariffs, shifts from fixed to flexible exchange rate system, and extensive privatisation of agricultural input procurement and distribution systems.

Following agricultural trade liberalization Tanzania's annual growth rate of maize production fluctuated between the high of 48.7 percent in 2008 and the lowest of -38.9 percent in
2009. The total annual production fluctuated between the 5,440,710 metric tons in 2008 and 1,485,000 metric tons in 1994. This was reflected in the actual cultivated land committed to maize production which also fluctuated between the high of 3,982,000 hectares in 2010 and the lowest of 957,500 hectares in 1999 (see Table 2). During the period 1990 and 2010 the consumption of maize constantly exceeded officially reported annual production. Ironically even in years where consumption outstripped production small quantities of maize were still reportedly exported, such as in 1990-91 (production 2,430,000 metric tons: consumption 2,636,000 metric tons: export 14000 metric tons), 2006-07 (production 3,373,000 metric tons: consumption 3,450,000 metric tons: export 50,000 metric tons), and 2008-09 (production 3,634,000 metric tons consumption 3,750,000 metric tons export 15,000 metric tons). Even in 2007-2008 despite the international food price crisis that year Tanzania still reportedly exported 50,000 metric tons of maize even though the there was only a 10,000 metric ton surplus of production over consumption and the instituting crisis-induced export ban on maize' (Ahmed, Diffenbaugh, Hertel, \& Martin, 201:22). In fact there are clear policy inconsistencies around maize export. Ahmed, et al. (201:22) report that:

the government lifted a long standing ban on maize export around the same time that the East Africa Community was established in 1999. However, in 2003 the Ministry of Agriculture and Food Security imposed an export ban on maize by withdrawing export permits already issued to traders and suspending the issuance of new permits. In 2006 this ban was lifted for a month, and then re-imposed, before being lifted again in late 2010(Ahmed, et al., 201:22).

The policy fluctuations are not surprising in a country where agricultural productivity is so low to the extent that in many cases even basic staple food crop production cannot meet household needs least of all contribute to national food security (Runyoro, 2006). Even in post-liberalization period one Tanzanian farmer produces food only enough to feed two persons compared with European Union farmer's 130 people (Masalawala, 2010: 9). In a country where the average household size is fiveperson this means that the average smallholder farmer does not produce enough to feed their family through the year.

\section{Methodology and Data Analysis}

We use productivity, consumption and price of rice and maize to measure economic benefits of trade liberalization on smallholder farmers in Bangladeshand Tanzania. We analyse productivity, consumption and price data for the pre-and post-liberalization periods to examine the relationship between productivity and consumption, productivity and price. We use price growth/stability as the dummy forearnings potential for smallholder farmers. We examine the correlation between domestic and international prices of rice for pre-and post-liberalization periods in Bangladesh and maize for the post-liberalization periodin Tanzania to estimate impact of agricultural trade liberalization on price stability/volatility and food security. A key limitation of the data is that we could not access reliable data on maize prices in Tanzania in the pre-liberalization period, so we limited our analysis to the post-liberalization period. The objective was to estimate the 
divergence between sub-national and international trade prices in rice and maize for the case study countries.

Data on Tanzania has been particularly difficult to verify as there are conflicting statistics on agricultural production from different sources which creates challenges of reliability. Thus while we have accessed data from a number of sources, to ensure reliability, we cross-checked the sources against some published international sources particularly Food and Agricultural Organization [FAO] statistics and United States Department of Agriculture (USDA) to ensure standardization and quality of data.

The case for Bangladesh was much more straightforward as the Bangladesh Bureau of Statistics [BBS] has standardized data and the Ministry of Agriculture also has standardized agricultural statistics. Therefore data on rice productivity, inputs, prices etc was much more easily available and verifiable for the entire study period.

Tables 1 and 2 suggest that data for both case study countries was very similar in both pre-liberalisation and post-liberalisation. The values of standard deviations for all variables were larger in the post-liberalisation than in pre-liberation period suggesting that data are more dispersed away from the mean. The distribution of data is asymmetric - a deviation from a normal distribution.

\section{Rice and Maize Production}

Maize production in Tanzania increased dramatically in the post-liberalization period, particularly in the second phase of liberalization in the post-1996 period. However, there were also wide fluctuations in total production volumes particularly in the decade 2002-to-2011. There was also relatively constant alignment between productivity trend and trends in cultivated land area during the same period (Figure 1), a clear indication of the lack of crop intensification and low application of technological inputs such as irrigation, fertilizers and high yielding seed varieties. Thus it would appear that the growth in maize production in the post liberalization period was largely driven by expansionof cultivated arearather than input intensification. There is overall low use of improved maize varieties, chemical fertilizers and other technological inputs by smallholder farmers in Tanzania (Erenstein, Kassie, Langyintuo, \&Mwangi, 2011) and the fluctuations in productivity volume in the period 2002-2011 could be associated with weather variability (Rowhani, Lobellb, Linderman, \& Ramankutty, 2012).

The poor yield per hectare recorded even in the period of fastest growth in fertilizer use in the period 2003-2011 (Figure 8) is a clear indication of low productivity per capita due to the dominant position of smallholder farmers who do not use technological inputs.

In Bangladesh rice production experienced rapid technological transformation in the post-liberalisation period consisting primarily of a combination of intensive use of irrigation, fertilisers, and HYV seeds. Technological transformation impacted cropping patterns of rice with dynamic shifts in rice cultivation from local varieties to HYV rice, contributing to higher volume of total rice production. Thus while total cultivated land committed to rice production remained constant in both pre-and post-liberalization periods, total rice production rose gradually and the gap between total cultivated land and rice production widened especially from the year 2000 and beyond (Figure 2). This may be explained by the extensive adoption of technological inputs particularly irrigation, high yielding varieties, fertilizers and pesticides (Figure 3).

Thus rice yield per hectare and growth in production volumes closely aligned with production technology inputs (Figure 2; Figure 3).

Figure 4 and Figure 5 show that production and consumption of maize and rice in Tanzania and Bangladesh respectively were

Table 1: Descriptive statistics for Rice in Bangladesh for the period 1972-2010

\begin{tabular}{|c|c|c|c|c|c|c|c|c|}
\hline & \multicolumn{4}{|c|}{ Pre-liberalisation (1972-1985) } & \multicolumn{4}{|c|}{ Post-liberalisation (1986-2010) } \\
\hline & Mean & Std & Skew & Kurto & Mean & Std & Skew & Kurto \\
\hline Land (000 hct) & 10142.11 & 359.01 & -1.11 & 1.33 & 10964.87 & 1245.63 & 1.58 & 1.09 \\
\hline Production (000 tn) & 12799.50 & 1640.20 & -0.60 & -0.36 & 22301.98 & 5591.97 & 0.53 & -0.92 \\
\hline Yield (tonne/hect) & 1.26 & 0.13 & -0.33 & -0.49 & 2.02 & 0.33 & -0.13 & -1.36 \\
\hline Consumption (000 tn) & 13193.57 & 1046.48 & 0.08 & -1.21 & 22955.16 & 5355.05 & 0.39 & -1.31 \\
\hline Irrigation (000 hct) & 1134.93 & 303.01 & -0.29 & -1.12 & 3258.01 & 949.65 & 0.04 & -1.02 \\
\hline Fertiliser (000 tn) & 602.45 & 253.74 & -0.04 & -1.02 & 2331.45 & 645.60 & -0.34 & -0.82 \\
\hline
\end{tabular}

Table 2: Descriptive statistics for Maize in Tanzania for the period 1975-2010

\begin{tabular}{|c|c|c|c|c|c|c|c|c|}
\hline & \multicolumn{4}{|c|}{ Pre-liberalisation (1975-1995) } & \multicolumn{4}{|c|}{ Post-liberalisation (1996-2010) } \\
\hline & Mean & Std & Skew & Kurto & Mean & Std & Skew & Kurto \\
\hline Land (000 hct) & 1511.48 & 282.08 & 0.38 & -1.44 & 2312.09 & 991.60 & -0.07 & -1.21 \\
\hline Production (000 tn) & 2011.89 & 477.62 & 0.67 & -0.02 & 3317.62 & 1071.30 & 0.58 & -0.56 \\
\hline Yield (tonne/hect) & 1.33 & 0.21 & 2.68 & 9.19 & 1.70 & 0.61 & 1.23 & 0.84 \\
\hline Consumption (000 tn) & 1925.95 & 618.74 & -0.44 & -0.75 & 2927.67 & 564.66 & 0.25 & -0.85 \\
\hline Irrigation (000 hct) & 125.71 & 29.40 & -1.41 & 1.08 & 173.67 & 13.85 & -0.73 & -1.47 \\
\hline Fertiliser (000 tn) & 65.67 & 23.50 & -0.17 & -1.22 & 94.99 & 58.30 & 0.84 & -0.57 \\
\hline
\end{tabular}




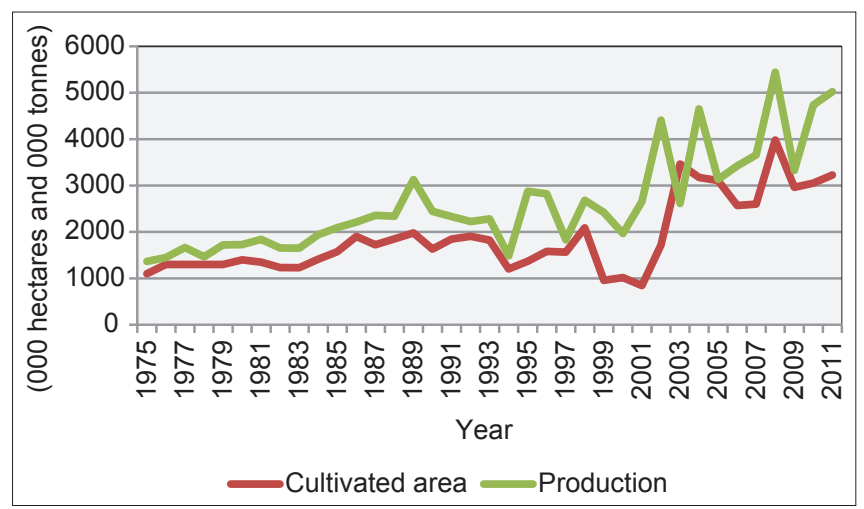

Figure 1: Maize production in Tanzania

Source: Calculated from FAOSTAT, FAO Statistics Division 2013 [26 June 2013]

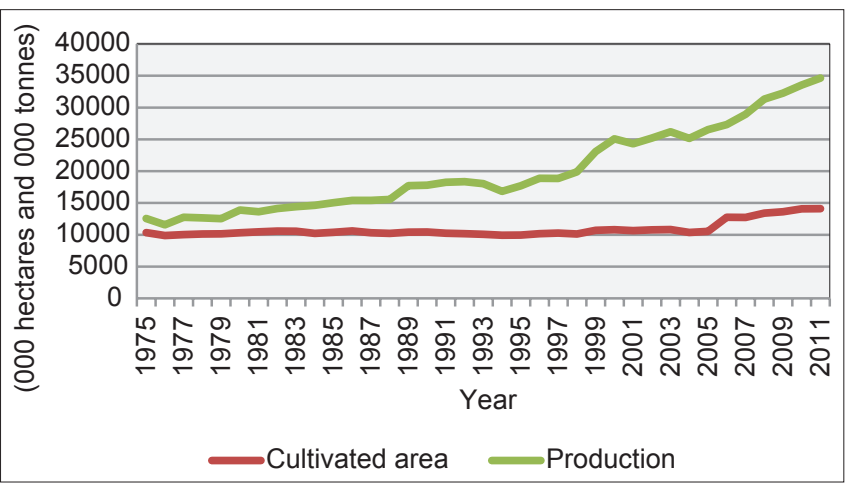

Figure 2: Rice production in Bangladesh

Source: Compiled and calculated from Handbook of Agricultural Statistics (Ministry of agriculture, 2007); Bangladesh Economic Review (Ministry of Finance, 2012)

relatively closely alignedin both the pre- and post-liberalization periods.

In the case of maize in Tanzaniathe area committed to maize production increased significantly from 1,905,000 hectares in 1986 to 3,050,700 hectares in 2010 although per capita production declined. Maize production exceeded consumption in the decade 2001-2011, albeit fluctuating widely (Figure 4), while rice consumption in Bangladesh slightly exceeded production in the post-liberalization period, until 2010 (see Figure 5).

Surplus of production over consumption would normally signal that maize farmers in Tanzania have moved beyond subsistence production, and would utilize the excess maize for trade resulting in income gains for farmers and improvement in their welfare. This domestic surplus would also provide maize for export to the international market, and Tanzania as a net exporter would benefit from trade liberalization if the international price of maize was favourable. Therefore price stability is an important variable in assessing the theoretical impact of trade liberalization.

\section{Maize and Rice Prices}

There is clear evidence in both countries that there is no integration between domestic and international prices of rice and maize (Figure 7 and Figure 8).

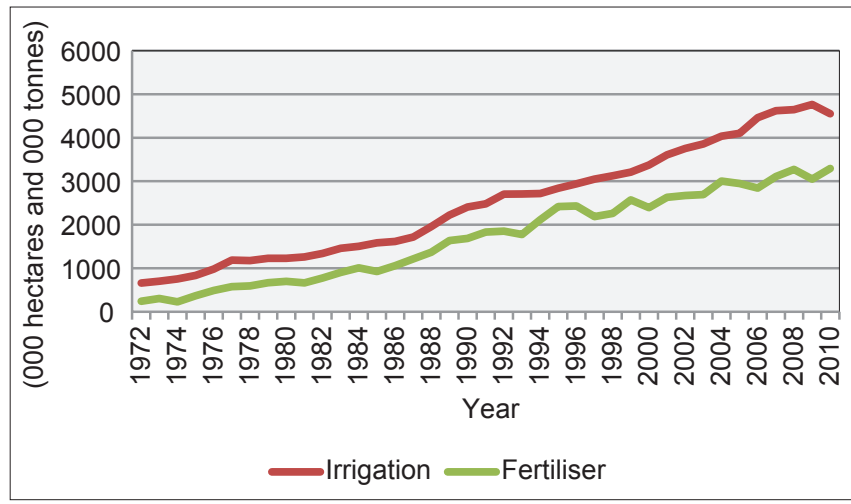

Figure 3: Bangladesh irrigated area and fertiliser use in rice production 1972-2010

Source: Compiled and calculated from Ministry of agriculture (2007), Ministry of Finance (2012), and BBS (1986)

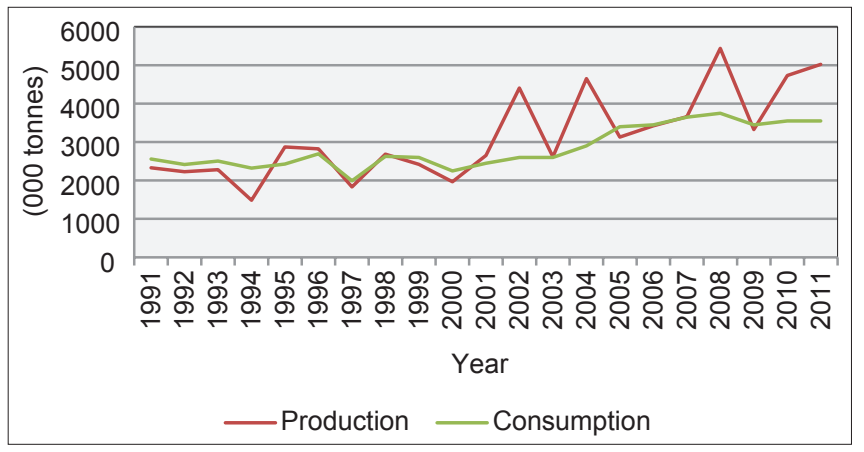

Figure 4: Maize production and consumption in Tanzania Source: Calculated from FAOSTAT, FAO Statistics Division 2013 [26 June 2013]

The producer price for rice in Bangladesh was relatively constant both in the pre-liberalization and post-liberalization period. However, there was upward trend in the post-liberalization period in world price, particularly from the year 2000 when the disparity between domestic and world prices widened considerably. This shows that international prices had only limited impact on domestic prices. Without effective market integration price volatility may in fact undermine trade efficiency. In the case of Bangladesh government ban on rice exports sought to achieve both domestic food security and to stabilize domestic consumer price. While these policy objectives were achieved, it also impacted on the producer prices which were consistently below both consumer price and world price (Figure 6). The implications of this are that the theoretical benefit of market access for rice producers boosting their income earnings was not realised. The paradox of this policy is that while consumer price decline benefits domestic consumers, some of whom may in fact be smallholder farmers who are net buyers in lean season and net sellers in high season, declining consumer price also implies decline in the welfare of smallholder rice farmers, particularly in local markets dominated by cartels who buy at low prices during harvest season and sell at high prices during lean seasons. Thus the net beneficiaries of the policy and imperfection in the rice market are rice traders and/ or intermediaries of syndicates rather than smallholder farmers. This complies with the suggestion that trade liberalization over 


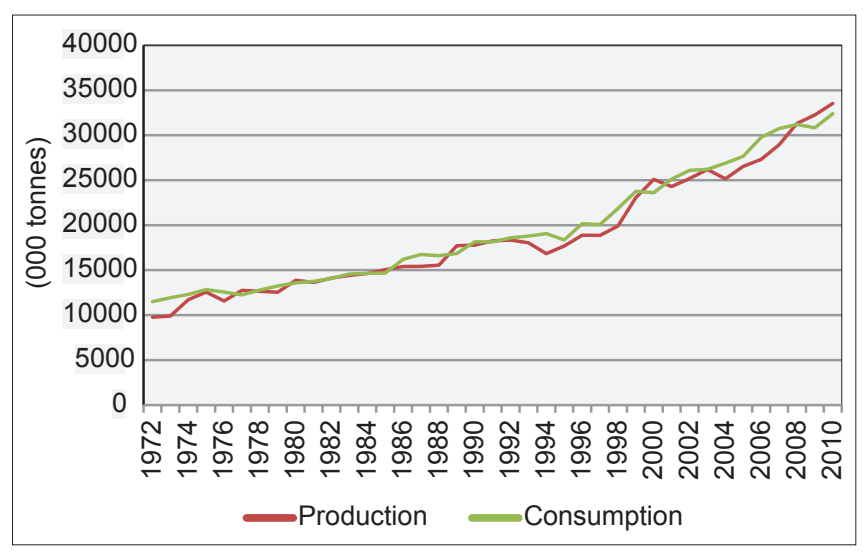

Figure 5: Rice production and consumption in Bangladesh 1972-2010 Source: Compile and calculated from Ministry of Agriculture (2007), Ministry of Finance (2012), and BBS (1986)

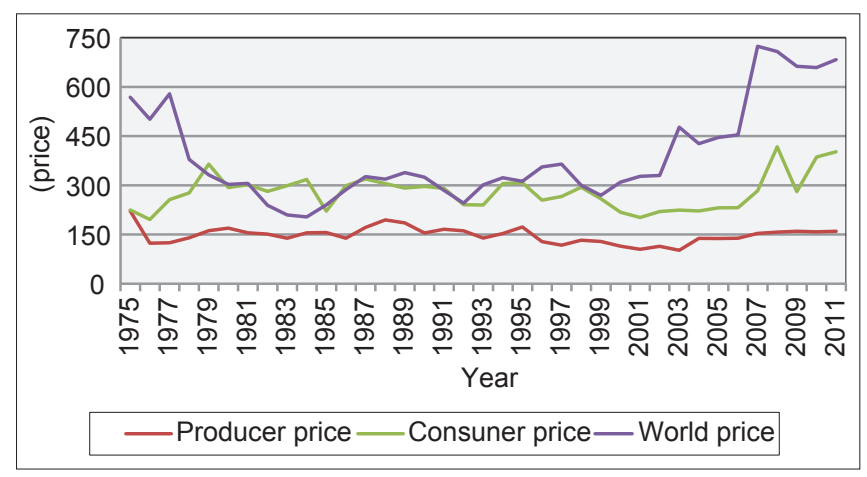

Figure 6: Rice price in Bangladesh (in US\$/tonne)

Source: World Rice Statistics, International Rice Research Institute (IRRI), http://ricestat.irri. org:8080/wrs2/entrypoint.htm

states the positive impact of competition (Sexton, Sheldon, McCorrison \& Wang, 2007). Thus while theoretically rice farmers in Bangladesh should benefit from trade liberalization because of the high world prices for rice since 2000, domestic policies have not allowed for these benefits to flow to smallholder farmers.

As in the case of Bangladesh, Tanzania also regulated the price of maize (although the policy fluctuated between strict price regulation and market-based pricing) and imposed maize exports ban to pre-empt shortage of maize in the domestic market. The paradox of these policies is that export bans invariably hurt smallholder farmers unable to earn adequate income from their maize production in a regulated market, but benefit consumers because of lower maize prices. Furthermore, export bans also encourage illegal cross-border trade with neighbouring fooddeficit countries further penalizing smallholder maize producers attempting to get a fair price on the open market, but benefit syndicates in cross-border smuggling and denying the country tax benefits from regulated cross-border trade.

A further paradox is that unlike Bangladesh, domestic maize prices in Tanzania were consistently higher than world prices during the period 2003-to-2010 until some form of convergence in the period 2011 (Figure 8). This finding leads

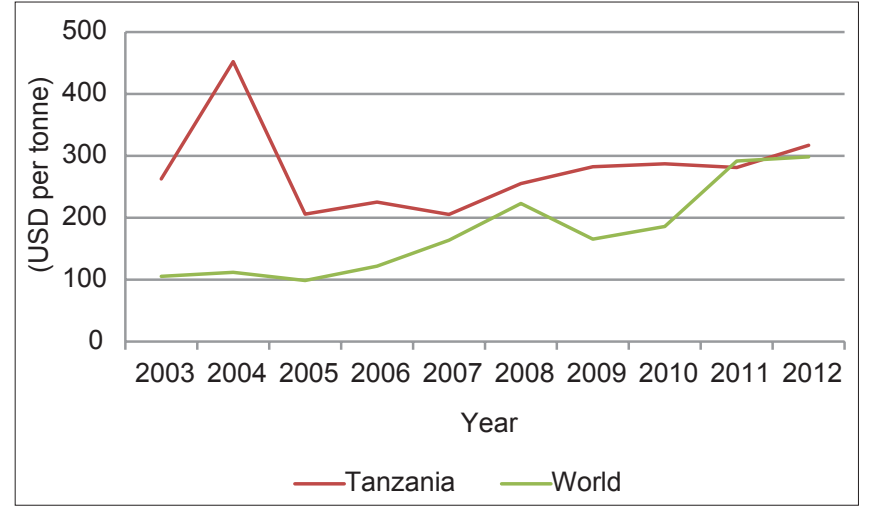

Figure 7: Maize price in Tanzania (in US\$/tonne)

Source: Regional Agricultural Trade Intelligence Network (RATIN), http://www.ratin.net/ index.php/tanzania

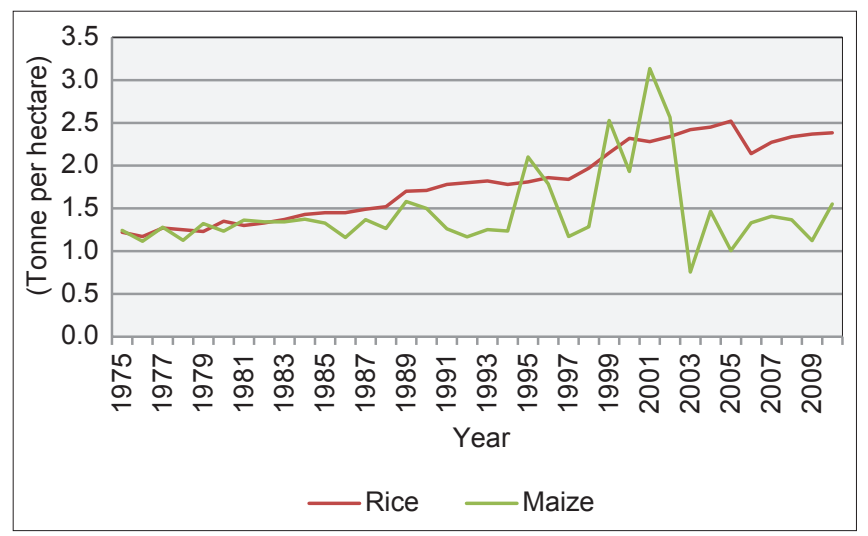

Figure 8: A comparison of yield of rice (Bangladesh) and maize (Tanzania)

Source: Rice data compiled from Ministry of agriculture (2007), Ministry of Finance (2012); and maize data compiled from calculated from FAOSTAT, FAO Statistics Division 2013 [26 June 2013]

us to question the theoretical justification for encouraging domestic production of maize because it would be cheaper for the country to import maize from the international market. Eventhough this would further depress the earning potential for smallholder maize farmers who depend on its production both for subsistence and income.

At the same time it also contradicts the argument that trade liberalization will negatively affect the welfare of maize farmers because the comparative advantage of high-income countries will dampen maize prices for local farmers because of cheap imports. Ina case where domestic prices have been consistently higher than world prices positive gains may be derived both from production gains on domestic market prices and consumption gains from international imports market prices. These findings further add to the theoretical ambiguity of the effects of agricultural trade liberalization in least developed economies such as Tanzania.

\section{Discussion and Conclusions}

The theoretical proposition is that agricultural trade liberalization positively impacts on the welfare of smallholder rice and maize farmers in Bangladesh and Tanzania respectively through 
productivity increases, exposure to markets and income earnings potential through access to open national and international markets. Smallholder farmers' welfare will therefore depend on the correlation between production, consumption, prices and income. While there is evidence of overall productivity increases in both rice in Bangladesh and maize in Tanzania, average maize yield in Tanzania collapsed and went below the pre-liberalization levels in the decade 2002-2011. These could be explained by the more extensive use of input technology in the production of rice by Bangladesh smallholder farmers compared with very low adoption/access to input technology for maize production particularly irrigation and high yielding varieties in the post-liberalization period by Tanzania's smallholder farmers. However, productivity growth did not necessarily lead to earnings gains for smallholder farmers in either Bangladesh or Tanzania due to price volatility and lack of market integration.

The empirical evidence of the extent to which commodity price volatility affects the income of smallholder farmer households and their vulnerability to poverty and food insecurity is best analysed using coefficient of variation of the level of prices (CV) and corrected coefficient of variation (CCV) as measured by Huchet-Bourdon (2011).

$$
\begin{aligned}
& C V=\frac{\text { Standard deviation }(\sigma)}{\operatorname{Mean}(\mu)} \times 100=\frac{\frac{\sqrt{\sum_{i=1}^{n}\left(X_{i}-\mu\right)^{2}}}{N}}{\frac{\sum_{i=1}^{n} X_{i}}{N}} \times 100 \\
& C C V=C V \sqrt{\left(1-R^{2}\right)}
\end{aligned}
$$

This requires time series commodity price to estimate income uncertainty that emanate from price and production volatility under different scenarios of exposure to the international and the domestic market shocks for single community smallholder farmers. Statistical analyses of price volatility over the pre- and postliberalization period for maize in Tanzania and rice in Bangladesh provide indicative assessment of how price volatility over the study period impacts on the welfare of smallholder producers. We define price volatility as high deviation from mean. We use coefficient of variation because it does not depend on the unit of measurement, especially as we are working with two products from two countries albeit over similar time periods. Our analysis focuses on historical volatility based on recorded prices both preand post-liberalization. Because we could not get reliable verified maize price data for Tanzania pre-liberalization we present only the post-liberalization analysis. We use local currency to reduce the effects of exchange rate as smallholder farmers trade on the local markets in local currency rather than US dollars.

The larger the values of both CV and CCV the greater the price volatility. The values of CV and CCV for producer price for both pre-liberalisation and post-liberalisation periods for Bangladesh were similar, suggesting less volatility in producer price of rice. However, the values of both CV and CCV for consumer price in the post-liberalisation were larger than that in the preliberalisation period, suggesting greater volatility of consumer price of rice in the post-liberalition period. Similarly, both CV and CCV for Tanzania were quite high, in fact higher than for Bangladesh, suggesting even greater volatility. This price volatility has serious implications for smallholder farmers as they experience losses at two levels, namely low producer price and high consumer price because they sell rice at low producer price immediately after harvest to repay loans and meet household expenditure and buy at high consumer price during the lean season to feed their families.

The theoretical outcome of enhanced welfare from trade liberalization can only be achieved where smallholder farmers are able to sell their produce at the best possible price in a stable predictable market. Price volatility has important implications for how smallholder farmers allocate their resources and how they behave both as producers/sellers in high season and consumers/buyers in low season. Price volatility also erodes market confidence and reduces food security for smallholder farmer households. Price volatility exposes poor consumers who are net-deficit producers, net-deficit sellers and surplus producers because their purchasing power is significantly reduced by sharp seasonal price rises. This is especially significant for Tanzania's three million maize producer-households, who constitute approximately 85 percent of total maize producers in Tanzania because they sell when the prices are low during the harvest season and buy when the prices are high during the lean season. Because their productivity is low and they do not have storage facilities they are exposed to the worst of the price volatility.

Although the price volatility is clear from the graphs in Figures 6 and 7 , and Table 1, it is important to undertake some statistical tests of means and equality of variance to determine whether the observed changes are statistically significant.

The comparison of mean data suggests that there was a larger reduction in producer price of rice in the post-liberalisation than that in the consumer price, suggesting that the welfare gains for smallholder rice farmers was not significant despite increased rice production in the post-liberalisation period. Paradoxically, the mean domestic maize price was significantly greater than world price, suggesting welfare gains by maize producers but a loss of welfare by maize consumers who in fact may be smallholder farmer households. This contradiction indicates inefficacy in maize markets, and more effective use of resources would be for the government to import maize at a cheaper world price and production factors for maize re-allocated in favour of other more efficient economic activities.

The impact of trade liberalization on the price of maize is mixed. Domestic prices trended above international prices for the entire post-liberalization period except for the brief period of the food crisis of 2007-2008. The theoretical position that trade liberalization increases export has not borne out in Tanzania. A more close examination of the workings of the domestic market will help understand the price movements. For example, what policy interventions will enable market integration given the complex nature of Tanzania's regional market? How could the capacity of the private sector be enhanced to provide reliable information on national and sub-national prices to ensure price equilibrium? 
Table 1: Coefficient of variation of the level of prices (CV) and corrected coefficient of variation for rice in Bangladesh and Tanzania

\begin{tabular}{|c|c|c|c|c|c|c|}
\hline & \multicolumn{4}{|c|}{ Rice (Bangladesh) } & \multirow{2}{*}{\multicolumn{2}{|c|}{$\begin{array}{c}\text { Maize (Tanzania) } \\
\text { Post-liberalisation } \\
(2003-2012)\end{array}$}} \\
\hline & \multicolumn{2}{|c|}{$\begin{array}{l}\text { Pre-liberalisation } \\
(1975-85)\end{array}$} & \multicolumn{2}{|c|}{$\begin{array}{c}\text { Post-liberalisation } \\
(1986-2011)\end{array}$} & & \\
\hline & CV & CCV & $\mathrm{CV}$ & $\mathrm{CCV}$ & $\mathrm{CV}$ & $\mathrm{CCV}$ \\
\hline $\begin{array}{l}\text { Producer } \\
\text { price }\end{array}$ & 29.47 & 13.12 & 29.81 & 15.63 & NA & NA \\
\hline $\begin{array}{l}\text { Consumer } \\
\text { price }\end{array}$ & 31.65 & 16.05 & 40.46 & 23.42 & 25.80 & 25.80 \\
\hline $\begin{array}{l}\text { World } \\
\text { price }\end{array}$ & 96.63 & 72.31 & 37.87 & 22.66 & 41.77 & 17.52 \\
\hline
\end{tabular}

Table 2: Comparison of mean

\begin{tabular}{|c|c|c|c|c|c|c|}
\hline & \multicolumn{4}{|c|}{$\begin{array}{c}\text { Rice price (USD/tonne) } \\
\text { (Bangladesh) }\end{array}$} & \multirow{2}{*}{\multicolumn{2}{|c|}{$\begin{array}{c}\text { Maize price (USD, } \\
\text { tonne) (Tanzania) } \\
\text { Post-liberalisation } \\
\text { (2003-2012) }\end{array}$}} \\
\hline & \multicolumn{2}{|c|}{$\begin{array}{c}\text { Pre-liberalisation } \\
\quad(1975-85)\end{array}$} & \multicolumn{2}{|c|}{$\begin{array}{c}\text { Post-liberalisation } \\
(1986-2011)\end{array}$} & & \\
\hline & Mean & $\begin{array}{c}\text { Std. } \\
\text { deviation }\end{array}$ & Mean & $\begin{array}{c}\text { Std. } \\
\text { deviation }\end{array}$ & Mean & $\begin{array}{c}\text { Std. } \\
\text { deviation }\end{array}$ \\
\hline $\begin{array}{l}\text { Producer } \\
\text { price }\end{array}$ & 154.30 & 26.59 & 144.99 & 24.25 & NA & NA \\
\hline $\begin{array}{l}\text { Consumer } \\
\text { price }\end{array}$ & 275.79 & 48.51 & 275.47 & 51.44 & 277.00 & 71.473 \\
\hline $\begin{array}{l}\text { World } \\
\text { price }\end{array}$ & 369.21 & 169.04 & 415.11 & 175.56 & 176.60 & 73.762 \\
\hline
\end{tabular}

The paradox of agricultural trade liberation in the case of rice in Bangladesh and maize in Tanzania is evidenced by policy fluctuations that produce both positive and negative consequences on the welfare of smallholder farmers. In both countries export bans have enabled self-sufficiency and food security in the staple food crop, rice and maize respectively. At the same time such bans invariably lead to illegal cross-border trade. Export restrictions also act as disincentives for rice and maize producers and limit market expansion where export growth could lead to increase in prices and make production more profitable.

Trade liberalization cannot be limited only to commodity trade, in this case rice and maize trade. This must be accompanied by liberalization in agricultural inputs and accompanying support for adoption of technological transformation inputs, more effectively using irrigation, fertilizer and high yielding varieties by smallholder farmers. These supplementary policy intervention explain why the welfare status of smallholder rice farmers in Bangladesh is considerably higher than smallholder maize farmers in Tanzania, albeit smallholder rice farmers are still relatively less well-off than medium and large rice farmers (Talkuder, 2011).

High dependence on rain-fed maize productivity by Tanzania's smallholder farmers results in low intensification and diversification, poor productivity in variable seasonal conditions, and low yield per hectare. Thus while smallholder maize farmers may be self-sufficient in subsistence maize, the policy outcome of trade liberalization to enhance income through trade has not been achieved for the estimated 85 percent of Tanzania's smallholder maize farmers who depend on it for income. For agricultural trade liberalization to achieve the envisaged theoretical outcomes for least developed economies such as Bangladesh and Tanzania productivity growth of staple food crops must be accompanied with other policy interventions that affect market competition, price integration and price stability so that smallholder farmers benefit both as producers and consumers. Policy fluctuations do not provide market confidence, and careful analysis of private sector capacity and development of rural infrastructure are important areas of intervention.

\section{References}

Acharya, S. (2011). Making Unilateral Trade Liberalisation Beneficial to The Poor. Socio-Economic Planning Sciences, 45(2) 60-71.

Adeoti, J.O., and Sinh, B.T. (2009). Technological Constraint and Farmers' Vulnerability in Selected Developing Countries (Nigeria and Vietnam). Paper presented at the 7th International Conference on 'Inclusive Growth, Innovation and Technological Change education, social capital and sustainable development' held on 6-8 October 2009, organized by the Global Network for the Economics of Learning, Innovation, and Competence Building Systems (Globelics), Dakar, Senegal.

Ahmed, S.A., Diffenbaugh, N.S., Hertel, T.W., \& Martin, W.J. (2012). Agriculture and Trade Opportunities for Tanzania: Past Volatility and Future Climate Change Review of Development Economics 16/3) 429-447.

Ahmed, S., and Sattar, Z. (2004). Trade Liberalization, Growth and Poverty Reduction The Case of Bangladesh. World Bank Policy Research Working Paper 34204, Washington DC: The World Bank.

Bangladesh, Bureau of Statistics. (1988). Household Expenditure Surveys 1972-86. Dhaka: Bangladesh Bureau of Statistics.

Bangladesh, Ministry of Agriculture.(2013). Bangladesh Agriculture at a Glance Retrieved from http//www.moa.gov.bd/statistics/bag.htm $26^{\text {th }}$ June 2013.

Bangladesh, Ministry of Agriculture. (2007). Handbook of Agricultural Statistics, December 2007. Dhaka: Ministry of Agriculture, Government of Bangladesh [Online]. Retrieved from http//www.moa. gov.bd/statistics/statistics.htm.15 ${ }^{\text {th }}$ May 2013.

Bangladesh, Ministry of Finance. (2012). Bangladesh Economic Review 2012. Dhaka: Ministry of Finance, the Government of Bangladesh.

Bangladesh, Ministry of Finance. (2009). Bangladesh Budget External Sector Retrieved from www.mof.gov.bd/en/budget/rw/external_sector.pdf. $26^{\text {th }}$ June 2013.

Bezemer, D., and Headey, D. (2008). Agriculture, Development, and Urban Bias. World Development, 36(8) 1342-1364.

Chang, R., Kaltani, L., and Loayza, N. V. (2009). Openness can be Good for Growth The Role of Policy Complementarities. Journal of Development Economics, 90(1) 33-49.

Economic and Social Research Foundation.(2010). Survey 2 Agricultural Trade Policies in Tanzania. In FAO (Ed.), Technical Compendium Description of Agricultural Trade Policies in Peru, Tanzania and Thailand. Environment and Natural Resource Management Working paper 36, BEFS Project, Food and Agriculture Organization (FAO). Retrieved from http//www.fao.org/docrep/013/al668e/al668e03.pdf $30^{\text {th }}$ June 2013.

Eicher, T. S., Mutti, J.H., and Turnovsky, M.H. (2009). International Economics. London Routledge.

Erenstein, O., Kassie, G.T., Langyintuo, A., and Mwangi, W. (2011). Characterization of Maize Producing Households in Drought Prone Regions of Eastern Africa. Nairobi, International Maize and Wheat Improvement Centre.

Falvey, R., Greenaway, D., and Silva, J. (2010). Trade Liberalisation and Human Capital Adjustment. Journal of International Economics, 81(2) 230-239.

Food and Agricultural Organization, Statistics Division.(2013). Statistical Year Book Retrieved from http//www.fao.org/statistics/en/ 26 th June 2013.

Foster, N. (2008). The Impact of Trade Liberalisation on Economic Growth Evidence from a Quintile Regression Analysis. KYKLOS, 61(4) 543-567.

Gingrich, C.D., and Garber, J.D. (2010). Trade Liberalization's Impact on Agriculture in Low Income Countries A Comparison of El Salvador and Costa Rica. Journal of Developing Areas, 43(2) 1-17.

Huchet-Bourdon, M. (2011). Agricultural Commodity Price Volatility An Overview. OECD Food, Agriculture and Fisheries Papers, No. 52, 
OECD Publishing. http//dx.doi.org/10.1787/5kg0t00nrthc-en

International Rice Research Institute (IRRI). (2013). World Rice Statistics. Retrieved from http//ricestat.irri.org8080/wrs2/entrypoint.htm 01 July 2013

Islam, M.J., and Habib, S.M.A. (2007). International Financial Institutions in Bangladesh Implications of Selected Policies for Agriculture Sector and Rural Livelihood. Dhaka Development Research Network.

Keleman, A. (2010). Institutional Support and in Situ Conservation in Mexico Biases Against Small-scale Maize Farmers in Post-NAFTA Agricultural Policy. Agriculture and Human Values, 27(1) 13-28.

Kilma, F.T.M., Chung, C., Kenkel, P., Mbiha, E.R. (2008). Impacts of Market Reforms on Spatial Volatility of Maize Prices in Tanzania Journal of Agricultural Economics 59(2) 257-270.

Klytchnikova, I., and Diop, N. (2006). Trade Reforms, Farms Productivity, and Poverty in Bangladesh. World Bank Policy Research Working Paper 3980, Washington DC the World Bank.

Krueger, A.O. (2010). Trade Liberalisation and Growth in Developing Countries. In J. J. Siegfried (Ed.), Better Living Through Economics. Cambridge, MA Harvard University Press.

Masalawala, R. (2010). Food Security in Tanzania Enabling Environment, Opportunities and Constraints Spring Semester Capstone Workshop Columbia University USA Retrieved from http// www.sipa.columbia.edu/academics/workshops/documents/ FoodSecurityTanzaniaAIIFINALCLEAREDwithNamesoptimized.pdf. $15^{\text {th }}$ May 2013.

McCulloch, N., Winters, L.A., and Cirera, X. (2003). Trade Liberalization and Poverty $A$ handbook. London Centre for Economic Policy Research.

Meschi, E., and Vivarelli, M. (2009). Trade and Income Inequality in Developing Countries. World Development, 37(2) 287-302.

Montalbano, P. (2011). Trade Openness and Developing Countries' Vulnerability Concepts, Misconceptions and Directions for Research. World Development, 33(9) 1489-1502.

Mosley, P., and Chiripanhura, B. (2009). Liberalisation and Poverty in Africa Since 1990 - Why is the Operation of the 'Invisible Hand' Uneven? Journal of International Development, 21(6) 749-756.

Popli, G. K. (2010). Trade Liberalization and the Self-Employed in Mexico. World Development, 38(6) 803-813.

Rahman, T. (2008). Political Economy of Trade Liberalisation in Bangladesh Impact of Trade Liberalisation on Bangladesh Agriculture. Jaipur CUTS International.

Regional Agricultural Trade Intelligence Network Tanzania Prices for Maize in PRICES FOR USD/M (RATIN). Retrieved from http//www.ratin.net/ index.php/tanzania $26^{\text {th June } 2013 .}$

Rodriguez, F. (2007). Openness and Growth What have We Learned? DESA Working Paper No 51, New York Department of Economic \& Social Affairs, United Nations.
Rowhani,P., Lobellb, D.B., Linderman, M. andRamankutty, N. (2012). Climate variability and crop production in Tanzania. Agricultural and Forest Meteorology 151, 449-460.

Runyoro, G.T. (2006). Globalization and Food Security in Tanzania in L.S Msambichaka Globalization and challenges for development in Tanzania. - Dar es Salaam, Tanzania Dar es Salaam University Press, p. 376-406 Retrieved from http//www.econbiz.de/en/search/detailedview/doc/all/globalization-and-food-security-in-tanzania-runyorogerald/10003774942/?no_cache=101 ${ }^{\text {st } J u l y ~} 2013$.

Sarris, A., Savastano, S. andChristiaensen, L. (2006). The role of agriculture in reducing poverty in Tanzania A household perspective from rural Kilimanjaro and Ruvuma. FAO Commodity and Trade Policy Research Paper No. 19Rome, FAO Information Division.

Sexton, R.J., Sheldon, I., McCorriston, S., Wang, H. (2007). Agricultural trade liberalization and economic development The role of downstream market power. Agricultural Economics 36, 253-270.

Skartein, R. (2005). Economic Liberalization and Smallholder Productivity in Tanzania From Promied Success to Real Failure, 1985-1998 Journal of Agrarian Change 5(3) 334-362.

Susila, W.R., and Bourgeois, R. (2008). Effect of Trade and Growth on Poverty and Inequality Empirical Evidences and Policy Options. Forum Penelitian Agro Ekonomi, 26(2) 71-81.

Stone, S.F., and Shepherd, B. (2011). Dynamic Gains from Trade The Role of Intermediate Inputs and Equipment Imports. OECD Trade Policy Working Paper No. 110

Talukder, D. (2011). Impact of Agricultural Trade Liberalization on the Welfare of Rural Communities in Bangladesh Unpublished PhD Thesis Submitted to Auckland University of Technology Auckland New Zealand.

Tanzania Agricultural Trade Information Centre.(2013). Overview of Tanzania's Agricultural Trade. Retrieved from http//www.agriculture. go.tz/attached\%20web\%20pages/TATIC/Economy\%20Files/ Economics\%20News.htm. 26 $6^{\text {th }}$ June 2013.

Williams, T.O., and Smith, R. (2008). Rethinking Agricultural Development The Caribbean Challenge. Paper presented at the XL $\left(40^{\text {th }}\right)$ Annual Monetary Studies Conference, 11-14 November 2008, Basseterre, St Kitts. Retrieved from http//www.ccmf-uwi.org/files/publications/ conference/1004.pdf $15^{\text {th }}$ May 2013.

Zhang, W.B. (2008). International Trade Theory Capital, Knowledge, Economic Structure, Money, and Prices over Time. Springer-Verlag Berlin Heidelberg.

How to Cite: Chile LM and Talukder D. 2014. The Paradox of Agricultural Trade Liberalization in Bangladesh and Tanzania American Journal of Trade and Policy, 1, 23-31.

Source of Support: Nil, Conflict of Interest: None declared. 